\title{
Evaluasi Praktik Pengalaman Lapangan Terhadap Dampak Penyelesaian Skripsi Mahasiswa IAIN Curup
}

\author{
Beni Azwar \\ Institut Agama Islam Negeri (IAIN) Curup \\ beniazwar@iaincurup.ac.id \\ Wandi Syahindra \\ Institut Agama Islam Negeri (IAIN) Curup \\ wandi.syahindra@gmail.com \\ Rini Widyastuti \\ Universitas Bung Hatta \\ riniwidyastuti@bunghatta.ac.id
}

\begin{abstract}
The research is behind the issue of policy change implementation of field experience practice of faculty Tarbiyah from 2 months to 4 months with the reason first, the student is less gaining knowledge and experience, secondly, the time of doing PPL on In January to March to coincide with the national exam, third, relating to the allocation of honors for teacher teachers that were calculated according to the number of students he was tutored, and fourth, with the change of the policy of PPL 4 months that effect on Completion of student thesis. The purpose of the research is to know the perception of the stake holder against PPL IAIN Curup and to know a formulation of PPL majors Tarbiyah LAIN Curup. The research method used is qualitative research using an analysis-descriptive approach. This study saw the implementation of PPL faculty Tarbiyah because the policy changes from 2 months to 4 months. The results showed the school's perception of PPL for paedagogic competence is still lacking, especially in classroom management, RPP manufacturing, and the development of learning evaluation tools. For personal competence is still low on student discipline and managing emotions, while for social competence most students impress their exclusive neighbors.
\end{abstract}

Keywords: Policy, evaluation, competence, field experience practice

Abstrak: Penelitian ini dilatarbelakangi masalah perubahan kebijakan pelaksanaan Praktik Pengalaman Lapangan Fakultas Tarbiyah dari 2 bulan menjadi 4 bulan dengan alasan; Pertama, mahasiswa kurang mendapatkan ilmu dan pengalaman; Kedua, waktu pelaksanaan PPL pada bulan Januari s.d. maret bertepatan persiapan ujian nasional; Ketiga, berkaitan dengan alokasi honor untuk guru pamong yang dihitung sesuai dengan jumlah mahasiswa yang dibimbingnya; dan Keempat, dengan perubahan kebijakan PPL 4 bulan yang berpengaruh pada penyelesaian skripsi mahasiswa. Tujuan penelitian adalah untuk mengetahui persepsi stake holder terhadap PPL IAIN Curup dan untuk mengetahui rumusan PPL Jurusan Tarbiyah IAIN Curup. Metode penelitian yang digunakan adalah penelitian kualitatif dengan menggunakan pendekatan analisis-deskriptif. Penelitian ini melihat pelaksanaan PPL Fakultas Tarbiyah karena perubahan kebijakan dari 2 bulan menjadi 4 bulan. Hasil penelitian menunjukkan persepsi sekolah terhadap mahasiswa PPL untuk kompetensi paedagogik masih kurang, terutama dalam pengelolaan kelas, pembuatan RPP, dan pengembangan alat evaluasi belajar. Untuk kompetensi personal masih rendah pada disiplin mahasiswa dan mengelola emosi, sedangkan untuk kompetensi sosial kebanyakan mahasiswa terkesan eksklusif mereka bergaulsesama mereka.

Kata Kunci : Kebijakan, Evaluasi, Kompetensi, Praktik Pengalaman Lapangan 


\section{PENDAHULUAN}

Pendidikan adalah usaha sadar yang bertujuan untuk mendewasakan individu dalam mencapai tugas-tugas perkembangannya. Djunaidi Hadisumarto menegaskan bahwa pendidikan yang mampu memfasilitasi berbagai perubahan adalah pendidikan yang merata, bermutu, dan relevan dengan kebutuhan masyarakatnya (Hadisumarto,2001). Unsur terpenting dalam pendidikan adalah peserta didik yang dalam kapasitasnya sebagai manusia di samping makhluk Tuhan juga merupakan makhluk individual dan sosial. Untuk itu, ia harus berkembang sesuai karakteristik kemanusiaannya (Fathurrochman, 2019). Lebih lanjut tentang manusia sebagai unsur penting pendidikan menurut Islam haruslah diarahkan pada pengembangan sintesa dialektika perkembangan dunia di mana ia berada dengan wahyu Ilahi (Mulkhan, 1993). Yahya A. Muhaimin mensinyair setidaknya terdapat 3 permasalahan yang menonjol, yaitu: (1) masih rendahnya pemerataan memperoleh pendidikan, (2) masih rendahnya mutu dan relevansi pendidikan, dan (3) masih lemahnya manajemen pendidikan, disamping belum terwujudnya keunggulan ilmu pengetahuan dan teknologi di kalangan akademisi dan kemandirian (Muhaimin, 2001).

Sebagai Lembaga Pendidikan Tenaga Kependidikan (LPTK), Jurursan tarbiyah IAIN Curup wajib melaksanakan pengalaman lapangan di bidang kependidikan bagi mahasiswanya agar dapat mempersiapkan diri menjadi guru profesional di bidangnya. Pengalaman lapangan ini merupakan penerapan dari konsep dan teori yang sudah dipelajari pada perkuliahan sebeluimnya. Selama ini pengalaman tersebut diberikan dalam sebuah mata kuliah Praktik Profesi Keguruan Terpadu (PPL) yang dimanifestasikan dalam praktik mengajar disekolah/madrasah (realteaching) dan praktik pengadministrasian kependidikan sebelum mengambil mata kuliah ini mahasiswa harus menyelesaikan mata kuliah micro teaching.

Berdasarkan fenomena yang terjadi selama ini di jurusan Tarbiyah IAIN Curup, bahwa PPL yang digagas semenjak tahun 2001 (waktu itu baru jurusan PAI dan PBI) sampai tahun 2016 (sudah menjadi 6 (enam) program studi, yaitu; PAI, PBI, PBA, PGMI, MPI dan BKI). PPL dilakukan selama 2 (dua) bulan dengan mengambil durasi waktu semester VIII (disatukan dengan KKPM dan skripsi) yaitu Januari s.d. Maret setiap tahunnya. Permasalahan yang timbul dengan pola PPL seperti ini adalah Pertama, mahasiswa kurang mendapatkan ilmu dan pengalaman, karena waktu yang relatif singkat dengan 8 (delapan) minggu, sehingga kalau mahasiswa praktik mengajar sekali seminggu, maka mereka masuk kelas sebanyak 8 (delapan) kali. Dalam hal yang sama proses PPL dengan alokasi waktu terlihat bahwa; minggu pertama mahasiswa orientasi di sekolah dengan diskusi dengan pamong untuk melengkapi administrasi pembelajaran (silabus, RPP dan Program pembelajaran), minggu kedua dan 
ketiga mahasiswa masuk kelas dengan mengamati guru pamong mengajar. Minggu keempat sampai keenam mahasiswa melaksanakan praktik mengajar diawasi guru pamong secara tersupervisi. Minggu ketujuh dan kedelapan mahasiswa ujian pengambilan nilai praktik yang dihadiri oleh guru pamong dan dosen pembimbing lapangan (DPL).

Kedua, waktu pelaksanaan PPL pada bulan Januari s.d. maret menimbulkan masalah, karena bersamaan dengan waktu tersebut sekolah lagi disibukkan dengan persiapan ujian nasional dan Try out untuk persiapan ujian tersebut, sementara sekolah sesuai dengan surat rekomendasi dari Kepala Dinas Pendidikan kabupaten dan kepala kantor Kementerian Agama kabupaten harus menerima dan melayani kegiatan PPL tersebut. Salah satu dampaknya mahasiswa tidak diperkenankan praktik dikelas akhir (kelas VI SD, kelas VIII SMP/MTs dan kelas XII SMA/MA/SMK), disamping itu efektivitas bimbingan dari guru pamong kurang optimal, karena mereka harus focus pada kelas akhir. Ketiga, berkaitan dengan alokasi honor untuk guru pamong yang dihitung sesuai dengan jumlah mahasiswa yang dibimbingnya. Sesuai dengan SBU dari kementerian keuangan bahwa setiap mahasiswa yang dibimbing dihargai Rp.100.000,- (seratus ribu rupiah) dalam satu kali kegiatan, sehingga tinggal menjumlahkan berapa mahasiswa yang dibimbingnya, besaran honor tersebut belum termasuk potongan pajak. Dalam hal ini terjadi ketimpangan, karena kegiatan yang tadinya 2 (dua) bulan berubah menjadi 4 (empat) bulan, atau volume kerja bertambah tapi uang yang diterima tidak mengalami kenaikan. Demikian juga honor DPL, kepala sekolah dan kordinator pamong (wakil kepala sekolah), tetapi tidak begitu bermasalah karena penerimaan mereka lebih besar dibanding guru pamong. Keempat, dengan perubahan kebijakan PPL dari 2 (dua) bulan menjadi 4 (empat) bulan masalah lain terjadi adalah penyelesaian masa studi terlambat, karena terkendala penyelesaian tugas skripsi karena masa PPL yang relatif lama, sehingga akses ke kampus berkurang karena sibuk PPL, sementara ini jumlah mahasiswa tarbiyah yang akan diwisuda 395 orang dari 453 orang yang melaksanakan PPL tahun 2017.

\section{METODE PENELITIAN}

Pendekatan dalam penelitian ini adalah kualitatif, dengan metode deskriptif (Sugiyono, 2008), metode penelitian yang digunakan untuk pencarian fakta pada obyek yang alamiah dengan interpretasi yang tepat (Whitney dalam Anselm Strauss \& Corbin Juliet, 2007).

Untuk kelancaran proses penelitian perlu terlebih dahulu menarik benang merah antara kebijakan PPL dengan realitas pelaksanaan PPL dengan tujuan mempermudah melihat permasalahan yang merupakan kesenjangan teoritik dan empiric dari pelaksanaan PPL tersebut. Dalam hal ini yang subjek 
penelitian adalah sekolah nyang dijadikan praktik dengan jumlah 88 sekolah untuk tahun 2017, dengan sebaran 3 kabupaten, yaitu; Kabupaten Rejang Lebong, Kabupaten Kepahiang dan Kabupaten Lebong. Untuk sekolah yang akan dijadikan subjek penelitian adalah kepala sekolah, wakil kepala sekolah (kordinator pamong), guru pamong dan siswa tiap sekolah. Termasuk dalam hal ini pengambil kebijakan, yaitu kantor Kementerian Agama Kabupaten (Rejang Lebong, Kepahiang dan Lebong) yang membawahi MI, MTs dan MA. Sedangkan Dinas Pendidikan Kabupaten (Rejang Lebong, Kepahiang dan Lebong) yang menaungi SD, SMP, termasuk sekolah Islam terpadu dilingkungan kabupaten tersebut.

Untuk Dinas Pendidikan Provinsi Bengkulu yang menaungi SLTA (SMA dan SMK) yang sejak Oktober 2016 terjadi perubahan regulasi untuk SLTA pengelolaannya tidak lagi di Kabupaten/Kota, tetapi kembali ke Provinsi. Untuk Dinas Pendidikan Propinsi, Kabupaten/Kota dan Kemanag Kabupaten akan diwawancarai dampak kebijakan pelaksanaan Praktik Pengalaman Lapangan (PPL) Tahun 2017 Jurusan Tarbiyah IAIN Curup yang berkaitan dengan administrasi izin persuratan untuk Dinas Pendidikan dan Kemenag Kabupaten. Dalam hal ini juga laporan kegiatan PPL tahun 2017 dan evaluasi guru pamong yang ada di bawah 2 (dua) jenis instansi tersebut.

Langkah-langkah Prosedur kegiatan yang dilaksanakan dalam penelitian ini meliputi tiga tahap yaitu:

(1) Tahap persiapan

Menentukan subyek penelitian. Subyek utama penelitian adalah informan kunci (key informants) yang dapat memberi informasi kepada peneliti data yang terkait dengan evaluasi kebijakan pelaksanaan praktik pengalaman lapangan (PPL) tahun 2017 jurusan tarbiyah IAIN Curup. Adapun informan penelitian adalah: (a). Untuk Dinas Pendidikan dan Kemenag Kabupaten adalah Kepala bidang pendidikan dasar dan menengah, Kasi Pais dan Pontren, serta pengawas pada 3 (tiga) Kabupaten (Rejang Lebong, Lebong dan Kepahiang). (b). Sekolah yang dijadikan lokasi PPL tahun 2017, yaitu kepala sekolah/madrasah, wakil kepala sekolah dan guru pamong. Adapun sekolah/madrasah yang dijadikan lokasi PPL sebanyak 88 sekolah. (c). Mahasiswa peserta PPL.

(2) Pengembangan dan penyusunan

Tahap Pengembangan dan penyusunan instrumen pengumpulan data baik untuk wawancara, observasi, angket dan dokumentasi. Untuk wawancara akan disusun format wawancara dengan indikator relevan dengan judul; evaluasi kebijakan pelaksanaan praktik pengalaman lapangan (PPL) tahun 2017 jurusan 
tarbiyah IAIN Curup. Observasi yang dilakukan adalah observasi partisipan dimana peneliti terlibat langsung dalam suasana informan, mengenai format observasi disusun dengan indikator sesuai yang dibutuhkan observer.

Adapun angket dalam penelitian ini berkaitan persepsi untuk evaluasi PPL tahun 2017, sekolah yang akan diambil sebanyak 88 sekolah, angket akan disusun berdasarkan indikator yang relevan dengan pelaksanaan PPL tahun 2017 yang mengalami perubahan dari pelaksanaan yang hanya 2 (dua) bulan menjadi 4 (empat) bulan. Berkaitan dengan dokumen akan diambil laporan mahasiswa selama mengikuti PPL, disamping dokumen sekolah yang berkaitan dengan PPL. Seperti absensi mahasiswa selama PPL, kegiatan yang dilakukan, program PPL apakah kegiatan umum selama PPL atau program perbulan dan perminggu yang diketahui oleh guru pamong dan diketahui oleh kepala sekolah.

Tiga (3) tahap pelaksanaan, penggalian dan pengumpulan data melalui:

a. Wawancara kepada subyek penelitian, untuk mendapatkan data tentang permasalahan yang berkaitan dengan perubahan kebijakan dan dampak penyelesaian skripsi mahasiswa.

b. Observasi/pengamatan terhadap kondisi sekolah yang berkaitan dengan proses pembelajaran, penampilan mahasiswa praktikan. Ini menggunakan format observasi supervisi panitia dan dosen pembimbing lapangan (DPL).

c. Pengisian angket dilakukan pihak sekolah dengan tujuan untuk mendapatkan gambaran dari sekolah. Angket tersebut akan diolah dan diprosentasekan.

d. Dokumentasi data dilaksanakan sebagai alat kroscek dengan sumber data Lain, sekaligus untuk memperkaya dan melengkapi data penelitian.

e. Screening data. Data yang telah diperoleh melalui wawancara, angket, observasi, dan dokumentasi, diklasifikasi dan distruktur. Kemudian diseleksi, dan dimasukkan ke dalam kelompok-kelompok sesuai dengan permasalahan, yang secara khusus akan dijadikan alat evaluasi secara komprehensif dan spesifik dari pelaksanaan PPL tersebut.

\section{HASIL PENELITIAN DAN PEMBAHASAN}

Adapun sekolah yang dijadikan objek penelitian adalah sekolah yang menjadi tempat atau lokasi PPL tahun 2017. Untuk tahun 2017 terdiri dari 2 kabupaten, yaitu; Kabupaten Rejang Lebong dan kabupaten Kepahiang, dengan rincian sekolah sebagai berikut:

Tabel 1. Nama Sekolah Untuk Lokasi PPL di Setiap Kabupaten

\begin{tabular}{cccc}
\hline No & Sekolah & Lokasi & Prodi \\
\hline 1 & SMPN 02 Kepahiang & Kepahiang & PAI, PBI, BK \\
\hline
\end{tabular}




\begin{tabular}{|c|c|c|c|}
\hline 2 & SMAN 1 Ujan Mas & Kepahiang & PAI, PBI, BK \\
\hline 3 & SMKN 01 Kepahiang & Kepahiang & PAI, PBI, BK \\
\hline 4 & MIS 01 Kepahiang & Kepahiang & PGMI, PAI, PBA \\
\hline 5 & MAS 01 Darussalam & Kepahiang & PAI, PBI, BK \\
\hline 6 & MTs. 01 Darussalam & Kepahiang & PAI, PBI, BK \\
\hline 7 & MIS 05 Darussalam & Kepahiang & PGMI, PAI, PBA \\
\hline 8 & MTs.N 01 Kepahiang & Kepahiang & PAI, PBI, BK \\
\hline 9 & MAN 1 Kepahiang & Kepahiang & PAI, PBI, BK \\
\hline 10 & MIN 03 Kepahiang & Kepahiang & PAI, PBI, BK \\
\hline 11 & MIN 04 Kepahiang & Kepahiang & PGMI, PAI, PBA \\
\hline 12 & SDN 06 Ujan Mas & Kepahiang & PGMI, PAI, PBA \\
\hline 13 & SMPN 2 Ujan Mas & Kepahiang & PAI, PBI, BK \\
\hline 14 & SMKN 1 Ujan Mas & Kepahiang & PAI, PBI, BK \\
\hline 15 & MTs. Al Munawaroh Kepahiang & Kepahiang & PAI, PBI, BK \\
\hline 16 & SMPN 1 Kepahiang & Kepahiang & PAI, PBI, BK \\
\hline 17 & SDN 4 Kepahiang & Kepahiang & PGMI, PAI \\
\hline 18 & SDN 04 Ujan Mas & Kepahiang & PGMI, PAI \\
\hline 19 & SDN 02 Ujan Mas & Kepahiang & PGMI, PAI \\
\hline 20 & SMAN 1 Merigi Kepahiang & Kepahiang & PAI, PBI, BK \\
\hline 21 & SDN 126 Rejang Lebong & Rejang Lebong & PAI, PBI, BK \\
\hline 22 & SDN. 17 Rejang Lebong & Rejang Lebong & PGMI, PAI \\
\hline 23 & SMPN 1 Rejang Lebong & Rejang Lebong & PAI, PBI, BK \\
\hline 24 & SDIT Khoiru Ummah & Rejang Lebong & PGMI, PAI \\
\hline 25 & SMKN 1 Rejang Lebong & Rejang Lebong & PAI, PBI, BK \\
\hline 26 & SMPN. 40 Rejang Lebong & Rejang Lebong & PAI, PBI, BK \\
\hline 27 & MIS GUPPI No 13 Tasik Malaya & Rejang Lebong & PGMI, PAI \\
\hline 28 & SMPN. 29 Rejang Lebong & Rejang Lebong & PAI, PBI, BK \\
\hline 29 & MIM Lubuk Kembang & Rejang Lebong & PGMI, PAI \\
\hline 30 & MA Baitul Makmur & Rejang Lebong & PAI, PBI, BK \\
\hline 31 & SMK-S 6 Pertiwi Curup & Rejang Lebong & PAI, PBI, BK \\
\hline 32 & SMP Aisyiah Rejang Lebong & Rejang Lebong & PAI, PBI, BK \\
\hline 33 & SMPN 2 Rejang Lebong & Rejang Lebong & PAI, PBI, BK \\
\hline 34 & MIN 03 Rejang Lebong & Rejang Lebong & PGMI, PAI, PBA \\
\hline 35 & SMKN 4 Rejang Lebong & Rejang Lebong & PAI, PBI, BK \\
\hline 36 & SMPN 14 Rejang Lebong & Rejang Lebong & PAI, PBI, BK \\
\hline 37 & SDN 51 Rejang Lebong & Rejang Lebong & PAI, PBI, BK \\
\hline 38 & SMAN 1 Rejang Lebong & Rejang Lebong & PAI, PBI, BK \\
\hline 39 & SDN 02 Rejang Lebong & Rejang Lebong & PAI, PBI, BK \\
\hline 40 & MA Muhammadiyah & Rejang Lebong & PAI, PBI, BK \\
\hline
\end{tabular}




\begin{tabular}{lllc}
\hline 41 & SDN 105 Rejang Lebong & Rejang Lebong & PAI, PBI, BK \\
\hline 42 & SMPN 05 Rejang Lebong & Rejang Lebong & PAI, PBI, BK \\
\hline 43 & SMPIT Rabbi Radhiyya & Rejang Lebong & PAI, PBI, BK \\
\hline 44 & SMKIT Rabbi Radhiyyah & Rejang Lebong & PAI, PBI, BK \\
\hline 45 & SMPN 3 Rejang lebong & Rejang Lebong & PAI, PBI, BK \\
\hline 46 & SDN 05 Rejang Lebong & Rejang Lebong & PGMI, PAI \\
\hline 47 & MIS Nurul kamal & Rejang Lebong & PGMI, PAI \\
\hline 48 & SDN 98 Rejang Lebong & Rejang Lebong & PGMI, PAI \\
\hline 49 & SDI Curup Timur & Rejang Lebong & PGMI, PAI \\
\hline 50 & MTs. Baitul Makmur Rejang Lebong & Rejang Lebong & PAI, PBI, BK \\
\hline 51 & SMAN 4 Rejang Lebong & Rejang Lebong & PAI, PBI, BK \\
\hline 52 & SMPN 4 Rejang Lebong & Rejang Lebong & PAI, PBI, BK \\
\hline 53 & SMPIT Khoiru Ummah & Rejang Lebong & PAI, PBI, BK \\
\hline 54 & SDN 18 Rejang Lebong & Rejang Lebong & PGMI, PAI \\
\hline 55 & SDUA Taman Harapan & Rejang Lebong & PGMI, PAI \\
\hline 56 & SDN 113 Rejang Lebong & Rejang Lebong & PGMI, PAI \\
\hline 57 & SDN 12 Rejang Lebong & Rejang Lebong & PGMI, PAI \\
\hline 58 & SDN 97 Rejang Lebong & Rejang Lebong & PGMI, PAI \\
\hline 59 & SMAN 8 Rejang Lebong & Rejang Lebong & PAI, PBI, BK \\
\hline 60 & MAS Ar Rahmah & Rejang Lebong & PAI, PBI, BK \\
\hline 61 & MIS Ar Rahmah & Rejang Lebong & PGMI, PAI \\
\hline 62 & MTs. Ar Rahmah & Rejang Lebong & PAI, PBI, BK \\
\hline 63 & SDN 2 Kepahiang & Rejang Lebong & PGMI, PAI \\
\hline 64 & SMKN 07 Rejang Lebong & Rejang Lebong & PAI, PBI, BK \\
\hline 65 & SMPN 10 Rejang Lebong & Rejang Lebong & PAI, PBI, BK \\
\hline 66 & MTs. Nurul Kamal & Rejang Lebong & PAI, PBI, BK \\
\hline 67 & SDN 01 Ujan Mas & Rejang Lebong & PGMI, PAI \\
\hline 68 & MAN Rejang Lebong & Rejang Lebong & PAI, PBI, BK \\
\hline 69 & SMAN 2 Rejang Lebong & Rejang Lebong & PAI, PBI, BK \\
\hline 70 & MIM 10 Karang Anyar & Rejang Lebong & PGMI, PAI \\
\hline & & \\
\hline
\end{tabular}

\section{Mahasiswa Praktikan}

Adapun mahasiswa yang praktik pengalaman lapangan jurusan tarbiyah terdiri dari program studi:

Tabel 2. Jumlah Mahasiswa PPL Jurusan Tarbiyah

\begin{tabular}{ccccc}
\hline \multirow{2}{*}{ No } & \multirow{2}{*}{ Prodi } & \multicolumn{2}{c}{ Jumlah } & \multirow{2}{*}{ Jumlah } \\
\cline { 3 - 4 } & & Reguler & Non Reguler & \\
\hline 1 & PAI & 175 & 30 & 205 \\
\hline
\end{tabular}




\begin{tabular}{clccc}
\hline 2 & PBI & 76 & 10 & 86 \\
\hline 3 & PGMI & 93 & 7 & 100 \\
\hline 4 & PBA & 39 & & 39 \\
\hline 5 & MPI/BKI & 14 & & 14 \\
\hline & Jumlah & $\mathbf{3 9 7}$ & $\mathbf{4 7}$ & $\mathbf{4 4 4}$ \\
\hline
\end{tabular}

Walaupun mahasiswa terbagi 2 kelompok (reguler dan non reguler) namun dalam pelaksanaannya kepanitiaan tidak dipisah, hanya saja mahasiswa reguler dan non reguler dipisahkan lokasi sekolahnya.

\section{Temuan Khusus}

Tabel 3. Presentase Observasi Sebelum Praktik

\begin{tabular}{lcccc}
\hline & Pawaban & Jumlah & $\%$ \\
\hline 1. Mahasiswa praktikan melakukan observasi & SL & 7 & 10 \\
\cline { 2 - 4 } kegiatan pembelajaran sebelum praktik & SR & 9 & 13 \\
\cline { 2 - 4 } mengajar untuk mengetahui karakteristik & $\mathrm{KD}$ & 25 & 36 \\
\cline { 2 - 4 } & siswa dalam mengikuti pembelajaran & $\mathrm{JR}$ & 18 & 26 \\
\cline { 2 - 4 } & $\mathrm{TP}$ & 11 & 16 \\
\hline \multicolumn{2}{c}{ Jumlah } & & 70 & 100 \\
\hline
\end{tabular}

Hal ini diperkuat dengan keterangan oleh wakil kepala sekolah urusan kurikulum yang mengatakan:

Sebelum pelaksanaan PPL beberapa bulan yang lalu memang ada mahasiswa yang datang untuk observasi, mereka masuk kelas dengan membawa format observasi, dan mengisinya.Ada juga yang mengisi sambil mengamati prilaku anak dalam bermain. Pada hakekatnya kami tidak keberatan sejauh tidak menganggu efektivitas kegiatan pembelajaran. Mereka membawa surat tugas dari kampus mereka. Pada tahun sebelumnya kegiatan ini tidak pernah dilakukan (Wawancara dengan Wakasek Ur.Kurikulum SMA 3 RL).

Hal senada juga dikatakan oleh AB guru SMA 4 RL, bahwa;

Beberapa bulan sebelum PPL mahasiswa datang ke sekolah, katanya mencari data berkaitan dengan kelemahan-kelemahan PPL pada tahun sebelumnya dan juga untuk mempelajari karakteristik siswa di sekolah ini, hanya saja mereka tidak didampingi oleh dosen mereka dan kegiatan ini hanya sekali dan kelemahannya mereka tidak melaporkan hasil dari observasinya kepada pihak sekolah, sehingga kami tidak tahu kondisi anak kami yang di observasi (Wawancara dengan guru PAI SMA 4 RL).

Pernyataan di atas berbeda dengan apa yang disampaikan oleh AM guru SD, bahwa: 
Sekolah kami merupakan sekolah baru dijadikan lokasi praktik mahasiswa, sebelumnya mereka tidak ada yang observasi untuk mengetahui kondisi siswa kami.Tatkala mereka datang baru mereka bertanya tentang karakteristik siswa, untuk PPL mereka kami tempatkan di kelas rendah dengan tujuan biar mereka lebih punya waktu untuk beradaptasi dengan siswa(Wawancara dengan AM guru SD 18 RL).

Tabel 4. Presentase Mengidentifikasi Kemampuan Siswa Sebelum Memberikan Pelajaran

\begin{tabular}{cccc}
\hline & Pawaban & Jumlah & $\%$ \\
\hline 2. Praktikan mengidentifikasikan kemampuan & $\mathrm{SL}$ & 3 & 4 \\
\cline { 2 - 4 } awal siswa sebelum memberikan pelajaran & $\mathrm{SR}$ & 4 & 6 \\
\cline { 2 - 4 } & $\mathrm{KD}$ & 9 & 13 \\
\cline { 2 - 4 } & $\mathrm{JR}$ & 31 & 44 \\
\cline { 2 - 4 } & $\mathrm{TP}$ & 23 & 33 \\
\hline Jumlah & & 70 & 100 \\
\hline
\end{tabular}

Berkaitan dengan identifikasi siswa sebelum pembelajaran guru ISN mengatakan:

Mahasiswa yang praktik di sekolah ini sebelumnya hanya 2 bulan dan kegiatannya kurang efektif, terutama dalam mengenali kemampuan siswa, karena semuanya serba tergesa-gesa. Pada saat PPL menjadi 4 bulan mahasiswa masih cara mereka mengidentifikasi kemampuan siswa masih kelihatan lemah, hanya menggunakan KKM, mereka lemah dalam evaluasi, baik yang berhubungan dengan jenis evaluasi yang sering dipakai dalam kurikulum 2013, cara pengolahan termasuk diagnostik bagi anak yang berkesulitan dalam belajar. Bagaimana menggunakan tes yang sesuai dengan karakteristik materi yang terdapat dalam silabus dan RPP (Wawancara dengan guru Bahasa Inggris SMA 4 RL.).

Pernyataan yang sama juga diungkapkan oleh ZM guru SMP 1 RL yang mengatakan;

Untuk tahun ini memang terjadi perubahan waktu PPL dari 2 bulan menjadi 4 bulan dan kami selaku pamong sangat mengapresiasi, hanya saja mungkin juga perlu peningkatan dari kualitas isi, diantaranya mengenali kemampuan siswa secara khusus, karena bahasa berbeda dengan yang lain. Banyak aspek yang harus dikenali, seperti kemampuan vocab, structure, reading, listening, dll. Salah satu mengenali kemampuan siswa dengan cara sering berkomunikasi dengan menggunakan bahasa Inggris (Wawancara dengan guru Bahasa Inggris SMP 1 RL). 
Tabel 5. Presentase Praktikan Memahami Kondisi Karakteristik Siswa Yang Menjadi Tanggung Jawabnya

\begin{tabular}{llcccc}
\hline \multicolumn{2}{c}{ Pernyataan } & & Jawaban & Jumlah & $\%$ \\
\hline 3. Praktikan & memahami & kondisi & SL & 18 & 26 \\
\cline { 3 - 5 } $\begin{array}{l}\text { karakteristik siswa yang } \\
\text { tanggung jawabnya }\end{array}$ & menjadi & SR & 13 & 19 \\
\cline { 3 - 5 } & & KD & 11 & 16 \\
\cline { 3 - 5 } & & JR & 19 & 27 \\
\cline { 3 - 5 } & Jumlah & & 70 & 13 \\
\hline
\end{tabular}

Sehubungan tabel di atas AI guru SMA 4 Rejang lebong mengatakan:

Pada umumnya anak-anak PPL dalam pembelajaran fokus pada siswa di kelas yang menjadi tanggung jawabnya, mereka lebih mudah akrab layaknya kakak dan adik karena usia mereka tidak terpaut jauh, hubungan itu seringkali berlanjut pada jam istirahat, bahkan ada yang di luar jam sekolah, kami juga tidak tahu apakah momen ini dijadikan alat untuk menganali karakteristik siswa, tetapi berkemungkinan mereka gunakan, karena mereka menurut mahasiswa PPL seringkali siswa itu curhat masalah pribadinya disamping juga masalah pelajaran(Wawancara dengan guru SMA 4 RL).

Hal ini dikuatkan oleh SM siswa SMA 4 Rejang lebong yang mengatakan:

Saya merasa lebih nyaman dan senang dengan mahasiswa PPL, terutama yang ngajar, di kelas saya, mereka sangat baik dan perhatian pada saya dan teman-teman, bahkan kadang-kadang saya ditraktir di kantin. Kalau kegiatan ekstrakurikuler seperti english dan diantar ke rumah(Wawancara dengan SM siswa kelas XI IIPA SMA 4 Rejang Lebong).

Berbeda dengan pernyataan AH kepala SMK 2 RL yang mengatakan:

Mahasiswa PPL di sekolah ini sangat menjaga jarak, terutama mahasiswa perempuan, karena di sekolah ini kebanyakan laki-laki. $\mathrm{K}$ juga bikinebanyakan mereka ngumpul sesama mereka, seperti di meja piket, di pustaka, di masdjid. Kami juga memahami karena mereka kadangkadang bandel dan sering iseng terhadap mahasiswa PPL, kadangkala mereka tidak melihat situasi dan tempat, sering bikin kesal, tetapi semakin kita menjauhi mereka, maka mereka semakin leluasa mempermainkan mahasiswa (Wawancara dengan Kepala SMK 1 RL).

Berbeda dengan penyataan guru SMPIT KU yang mengatakan:

Sekolah ini memakai 2 kurikulum, kurikulum nasional dan kurikulum keagamaan. Selama praktik ada mahasiswa yang terlalu menjaga jarak dengan siswa, hal berbeda-beda ada mahasiswa yang menjaga jarak dan ada juga siswa yang menjaga jarak.umumnya mahasiswa menjaga jarak, karena takut ditanya hafalannya oleh siswa, karena rata-rata mereka hal 
jus 30, ini menyulitkan mahasiswa mengenali karakteristik siswa. Demikian juga di sekolah ini pergaulan dengan lawan jenis sangat diperhatikan (Wawancara dengan guru SMPIT KU RL).

Pernyataan ini juga diperkuat oleh guru SDIT RR yang mengatakan:

Dari sekian mahasiswa PPL di sekolah kami, pada umumnya dari segi akhlak mereka tidak bermasalah, disiplin mereka bisa datang pagi dan mengikuti semua agenda sekolah dengan baik.Yang sering bermasalah dalam ibadah, seperti; sholat, membaca Al Qur'an dan hafalan Al Qur'annya. Seringkali mereka tidak mau menyatu dengan siswa lantaran malu ditanya hafalannya sudah berapa juz?, kalau bisa kami dapat guru praktik yang memiliki hafalan yang minimal sama dengan siswa dan kalau bisa lebih lagi. Demikian juga tatkala diminta jadi imam sholat banyak diantara mereka yang kurang percaya diri (Wawancara dengan Kepala SDIT RR).

Tabel 6. Presentase Persiapan Pisik Dan Psikis Praktikan Sebelum Pembelajaran Dimulai

\begin{tabular}{lccc}
\hline Pernyataan & Jawaban & Jumlah & $\%$ \\
\hline 4. Persiapan pisik dan psikis praktikan & $\mathrm{SL}$ & 12 & 17 \\
\cline { 2 - 4 } diperhatikan oleh praktikan sebelum & $\mathrm{SR}$ & 17 & 24 \\
\cline { 2 - 4 } pembelajaran dimulai & $\mathrm{KD}$ & 8 & 11 \\
\cline { 2 - 4 } & $\mathrm{JR}$ & 19 & 27 \\
\cline { 2 - 4 } & $\mathrm{TP}$ & 14 & 20 \\
\hline Jumlah & & 70 & 100 \\
\hline
\end{tabular}

Sehubungan dengan tabel di atas kepala SMP 5 Rejang Lebong mengatakan; Awalnya mahasiswa masuk kelas kurang percaya diri, karena baru pertama kali masuk kelas dengan praktik mengajar yang sebenarnya.Dari persiapan pisik sebelumnya mereka diarahkan seperti pakaian, rambut, sepatu, dll.Mereka dituntut agar lebih rapi dan tidak norak, baik dari model dan warna.Sedangkan untuk persiapan mental agar mereka dapat menumbuhkan kepercayaan diri yang baik dalam berhadapan dengan siswa, mereka harus lebih banyak berlatih dan memperhatikan bagaimana sebelumnya kami sebagai pamong mereka mengajar di kelas(Wawancara dengan guru PAI SMP 5 RL (Bapak BT), tanggal, 25 Juli 2018).

Pernyataan tersebut juga dikuatkan oleh DM guru SDIT RR, yang mengatakan;

Kami percaya bahwa dikampus melalui mata kuliah mikro teaching mahasiswa sudah disiapkan untuk berpraktik di sekolah, dari penampilan pisik awalnya mereka berpenampilan yang agak norak dengan dandanan menor dan kurang cocok dengan karakteristik sekolah Islam terpadu, dari tingkah laku juga 
masih kelihatan sering cengengesan dan tertawa berlebihan sehingga anak-anak kami merasa aneh melihatnya yang dinilainya kurang menjaga diri. Akhirnya kami panggil dan nasehati, mereka dilibatkan pada sholat duha berjamaah, sholat zuhur dan ashar berjamaah dan diikutkan dalam liqo (pengajian rutin) yang akhirnya mereka dapat beradaptasi dengan lingkungan sekolah (Wawancara dengan guru SDIT RR (Ibu DM), tanggal 27 Juli 2018).

Tabel 7. Presentase Praktikan Menyusun Silabus Sebelum Praktikan Mengajar Di Kelas

\begin{tabular}{|c|c|c|c|}
\hline $\begin{array}{l}\text { Pernyataan } \\
5 . \quad \begin{array}{l}\text { Praktikan menyusun silabus sebelum } \\
\text { praktikan mengajar di kelas }\end{array}\end{array}$ & Jawaban & Jumlah & $\%$ \\
\hline \multirow{5}{*}{$\begin{array}{l}\text { 5. Praktikan menyusun silabus sebelum } \\
\text { praktikan mengajar di kelas }\end{array}$} & SL & 31 & 44 \\
\hline & SR & 9 & 13 \\
\hline & KD & 9 & 13 \\
\hline & JR & 17 & 19 \\
\hline & TP & 8 & 11 \\
\hline Jumlah & & 70 & 100 \\
\hline
\end{tabular}

Berkaitan dengan paparan diatas masih terdapat perbedaan antara satu sekolah dengan sekolah lainnya. Seperti yang dikemukakan SMA 1 Merigi NV yang mengatakan, bahwa;

Mahasiswa PPL di sekolah ini karena sudah belajar bagaimana cara membuat RPP yang merupakan turunan dari silabus, mereka sudah membuat sendiri. Kami sebagai pamong hanya menambahkan dan menyesuaikan dengan karakteristik siswa dan materi pelajaran.Dari susunan RPP sudah sesuai standar, kami hanya menyempurnakan metode, media dan alat evalusi yang diigunakan, termasuk buku-buku paket yang digunakan dalam pelajaran yang diampu, kebetulan saya memamongi PAI (Wawancara dengan DR guru PAI SMA Merigi, tanggal 23 Juli 2018.).

Menanggapi masalah diatas pendapat berbeda dikemukakan DS guru SMPIT KU yang mengatakan:

Di sekolah ini mahasiswa PPL selalu membuat ulang RPP, kami bukan kurang percaya dengan RPP yang dibawa dari kampus, yang jadi masalah RPP tersebut tidak sesuai dengan karakteristik sekolah yang kami punya, karena di sekolah ini memakai dua kurikulum, yaitu kurikulum Diknas dan Kurikulum Kemenag, walaupun untuk mata pelajaran di luar keagamaan, seperti bahasa inggris tetap saja harus diinfusikan materi keagamaan, minimal dalam bentuk contoh materi yang diberikan ke siswa. Penekanan yang paling penting yaitu dari karakter yang diinginkan dalam materi pelajaran tersebut dan alat evaluasi yang digunakan (Wawancara dengan DS guru SMPITKU, tanggal 24 Juli 2018).

Menanggapi hal diatas kepala SMPITKU mengemukakan, bahwa: 
Untuk mengatasi itu kami melibatkan mahasiswa dalam kegiatan MGMP sekolah, mulai dari silabus, RPP, materi yang diajarkan.Kemudian mereka diberikan tugas mandiri untuk menyusun silabus satu semester.Dalam pembuatan tugas tersebut mereka didampingi oleh pamong mereka masing-masing.Tugas itu diserahkan ke pamong untuk dikoreksi dan dikemballikan ke mahasiswa (Wawancara dengan BY kepala SMPITKU, tanggal 24 Juli 2018).

Tabel 8. Presentase Praktikan mengkonsultasikan RPP kepada guru pamong sebelum melaksanakan praktik pembelajaran

\begin{tabular}{|c|c|c|c|}
\hline & Jawaban & Jumlah & $\%$ \\
\hline \multirow{5}{*}{$\begin{array}{l}\text { 6. Praktikan mengkonsultasikan RPP } \\
\text { kepada guru pamong sebelum } \\
\text { melaksanakan praktik pembelajaran }\end{array}$} & SL & 8 & 11 \\
\hline & SR & 10 & 14 \\
\hline & KD & 19 & 27 \\
\hline & JR & 18 & 26 \\
\hline & TP & 15 & 21 \\
\hline Jumlah & & 70 & 100 \\
\hline
\end{tabular}

Berkaitan dengan data di atas pada umumnya mahasiswa senantiasa mengkonsultasikan dengan pamong mereka. Seperti yang dikemukakan oleh HY guru SMA 2 RL yang mengatakan, bahwa:

Sebelum praktik pembelajaran mahasiswa harus memperlihatkan RPP mereka ke saya, sekaligus kesiapan mereka mengajar, seperti; media yang digunakan. Konsultasi juga setelah mereka selesai praktik mengajar untuk membahas proses pembelajaran yang barusan dilakukan, kami sebagai pamong memberikan masukan untuk perbaikan kedepan, terutama dalam pengelolaan kelas. Seringkali mereka kurang bisa mengendalikan kelas.Seperti siswa ribut dan berbicara dengan teman sebangkunya, sementara mereka tetap lanjut mengajar (Wawancara dengan HY guru SMA 2 RL, tanggal 25 Juli 2018).

Berbeda dengan SMK Pertiwi yang mengatakan:

Untuk konsultasi RPP sebelum pembelajaran jarang kami lakukan, karena kami sudah yakin mereka sudah membuat RPP dengan benar.Hanya saja kami tetap menanyakan RPP sebelum mereka mengajar.Prinsipnya mereka harus membawa RPP ke dalam kelas, kalau tinggal disuruh ambil.Ini terbukti mereka lebih waspada dan selalu menyiapkan RPP setiap mau mengajar (Wawancara dengan DF guru SMK Pertiwi, tanggal 26 Juli 2018). 
Tabel 9. Praktikan Mengkonsultasikan RPP Kepada Guru Pamong Sebelum Melaksanakan Praktik Pembelajaran

\begin{tabular}{lccc}
\hline Pernyataan & Jawaban & Jumlah & $\%$ \\
\hline 7. Praktikan menyusun RPP sesuai dengan & SL & 19 & 27 \\
\cline { 2 - 4 } ketentuan sekolah & SR & 12 & 17 \\
\cline { 2 - 4 } & KD & 10 & 14 \\
\cline { 2 - 4 } & JR & 15 & 21 \\
\cline { 2 - 4 } & $\mathrm{TP}$ & 14 & 20 \\
\hline & & 70 & 100 \\
\hline
\end{tabular}

Menanggapi hal di atas pada dasarnya mahasiswa sudah diarahkan bahwa RPP yang dipakai dalam praktik mengajar di kelas yaitu yang sesuai dengan ketentuan sekolah, karena waktu mata kuliah mikro teaching diawal mata kuliah mahasiswa ke sekolah untuk mencari silabus dan bertanya dengan guru mata pelajaran. Namun demikian masih saja ada mahasiswa yang menyusun RPP diluar ketentuan sekolah, seperti yang dikatakan oleh guru MAN 2 Kepahiang AD yang mengatakan, bahwa:

Mahasiswa yang praktik disini dari program non reguler, mereka hadir di sekolah waktu ada jam mengajar saja, mereka umumnya dari guru yang sudah paham dengan RPP karena sudah lama mengajar, sehingga kami percaya saja bahwa RPP mereka sudah benar. Demikian juga mereka juga memiliki hubungan emosional yang cukup baik, sehingga kami kurang pantas untuk menyamakan dengan mahasiswa biasa (Wawancara dengan AD guru MAN 2 Kepahiang, 26 Juli 2018).

Hal ini juga diperkuat oleh LD guru MAN 2 Kepahiang yang mengatakan, bahwa:

Sebenarnya mahasiswa yang praktik tahun ini berbeda dengan tahun sebelumnya, kalau tahun sebelumnya mereka aktif dan waktunya lebih banyak di sekolah, sehingga banyak yang dapat dilakukan berkaitan dengan program sekolah, mulai dari mengajar sampai kegiatan ekstrakurikuler.Kalau sekarang mereka waktunya terbatas disamping umurnya lebih tua, sehingga ada rasa sungkan untuk memerintah mereka. Mereka di sekolah apabila ada jam mengajar saja, selebihnya mereka lebih banyak di sekolah tgempat mereka mengabdi. Berkaitan dengan RPP mereka sudah membawa RPP yang siap untuk masuk kelas (Wawancara dengan LD guru MAN 2 Kepahiang, 26 Juli 2018). 
Tabel 10. Praktikan Menyusun RPP Sesuai Dengan Materi Ajar

\begin{tabular}{lcccc}
\hline Pernyataan & Jawaban & Jumlah & $\%$ \\
\hline 8. Praktikan menyusun RPP sesuai dengan & SL & 20 & 29 \\
\cline { 2 - 4 } materi ajar & SR & 23 & 33 \\
\cline { 2 - 4 } & KD & 10 & 14 \\
\cline { 2 - 4 } & JR & 9 & 13 \\
\cline { 2 - 4 } & TP & 8 & 11 \\
\hline Jumlah & & 70 & 100 \\
\hline
\end{tabular}

RPP disusun sesuai materi ajar, karena dalam mata kuliah pengembangan bahan ajar, memang sudah disampaikan.Hal ini ditegaskan dalam pembekalan persiapan PPL, sehingga permasalahan ini tidak begitu banyak terjadi di sekolah. Seperti yang dikemukakan oleh ibu YF yang mengatakan bahwa dalam penyusunan RPP mahasiswa sudah mencocokkan dengan materi ajar, kami senantiasa mengoreksi apa yang dilakukan sebelum proses pembelajaran, buku rujukan yang dipakai, disamping sumber-sumber lain (Wawancara dengan YF guru MTs Nurul Kamal, 25 Juli 2018).

Tabel 11. Presentase Saranan dan Prasarana

\begin{tabular}{lcccc}
\hline Pernyataan & Jawaban & Jumlah & $\%$ \\
\hline 9. Saranan dan prasarana dipersiapkan & SL & 11 & 16 \\
\cline { 2 - 4 } $\begin{array}{l}\text { oleh mahasiswa praktik sebelum kegiatan } \\
\text { pembelajaran }\end{array}$ & SR & 13 & 19 \\
\cline { 2 - 4 } & KD & 19 & 27 \\
\cline { 2 - 4 } & JR & 18 & 26 \\
\cline { 2 - 4 } & TP & 9 & 13 \\
\hline & & 70 & 100 \\
\hline
\end{tabular}

Sebelum praktik pembelajaran mahasiswa menyiapkan segala sesuatu yang berkaitan dengan praktik pembelajaran, terutama seperti media atau alat peraga yang dipakai, atau kertas yang dibutuhkan untuk ulangan. Seperti yang dikatakan SP guru SMA 1 RL mengatakan:

Di sekolah ini hakekatnya sarana dan prasarana cukup memadai tetapi pemanfaatannya harus sesuai dengan mekanisme yang ada.Seperti pemakaian infocus harus melalui TU, tetapi untuk spidol dan kertas harus menyiapka sendiri, karena sekolah hanya menyiapkan untuk guruguru yang ada di sekolah ini.Sementara untuk ruangan tetap memakai ruangan kelas, kecuali kegiatan keagamaan harus di masdjid, seperti kegiatan Risma (Wawancara dengan Sp guru SMA 1 RL, 27 Juli 2018).

Berbeda dengan apa yang dikemukakan oleh EV dengan mengatakan:

Di sekolah ini sekolah swasta, sarana dan prasarana dalam pembelajaran sangat terbatas sekali, mahasiswa sebelum praktik pembelajaran harus 
menyiapkan sendiri.Pernah mereka dalam materi PAI ingin memutar film, mereka harus bawa infokus sendiri, kami tidak tahu mereka bisa meminjam dimana.Sekolah hanya menyediakan listrik. Demikian juga untuk sarana yang lain, seperti media, kertas, dll harus disiapkan sendiri (Wawancara dengnan EV guru MIS Lubuk Kembang, 27 Juli 2018).

Tabel 12. Presentase Praktikan Membuat Atau Memodifikasi Sarana Dan Prasarana Yang Tidak Dimiliki Oleh Sekolah Lokasi PPL

\begin{tabular}{lccc}
\hline Pernyataan & Jawaban & Jumlah & $\%$ \\
\hline 10. Praktikan membuat atau memodifikasi & SL & 13 & 19 \\
\cline { 2 - 4 } $\begin{array}{l}\text { sarana dan prasarana yang tidak dimiliki } \\
\text { oleh sekolah lokasi PPL }\end{array}$ & $\mathrm{SR}$ & 9 & 13 \\
\cline { 2 - 4 } & $\mathrm{KD}$ & 11 & 16 \\
\cline { 2 - 4 } & $\mathrm{JR}$ & 21 & 30 \\
\cline { 2 - 4 } & $\mathrm{TP}$ & 16 & 23 \\
\hline Jumlah & & 70 & 100 \\
\hline
\end{tabular}

Berkaitan dengan membuat atau memodifikasi sarana dan prasarana mahasiswa PPL, guru MIN Daspetah mengatakan:

Sekolah ini mahasiswa PPL lebih banyak dari prodi PGMI, dalam pembelajaran seringkali mereka menampilkan metode dan media yang kami di sekolah belum mempraktikan ke siswa sebelumnya.Mereka memiliki inovasi dan kreativitas dalam pembelajaran, sehingga kelas menjadi lebih hidup dan siswa termotivasi dalam pembelajaran.Padahal kadangkala diperhatikan media yang digunakan sangat sederhana dan tidak terlalu mahal (Wawancara dengan ibu SS guru MIN Daspetah, 30 Juli 2018).

\section{KESIMPULAN}

Berdasarkan hasil penelitian yang dilakukan maka dapat ditarik beberapa kesimpulan yang berkaitan dengan rumusan masalah: (1). Persepsi stake holder terhadap PPL IAIN Curup. Perubahan PPL dari 2 (dua) menjadi 4 (empat) bulan mendatangkan dampak, antara lain: (a). Respon sekolah sangat positif dengan perubahan regulasi PPL Fakultas Tarbiyah. (b). Permasalahan terbanyak lemahnya dasar-dasar ilmu kependidikan, seperti mata kuliah psikologi pendidikan, pengembangan kurikulum, pengembangan bahan ajar, metode dan media pembelajaran dan evaluasi pembelajaran. (c). Rendahnya pemahaman keagamaan mahasiswa praktik, seperti hafalan yang kurang, ibadah lain dan doadoa yang menjadikan mereka membatasi diri di sekolah, terutama di sekolahsekolah agama. (d). Disiplin dan kerjasama mahasiswa yang masih rendah, mahasiswa bergaul sesama mahasiswa. (2). Rumusan pelaksanaan PPL dapat disimpulkan menjadi: (a). Penguatan pada 4 (empat) kompetensi, yaitu 
kompetensi paedagogik, personal, sosial dan profesional. Penekanan lebih pada kompetensi paedagogik, personal dan sosial. (b). Rumusan prilaku dan etik mahasiswa praktik, setiap pelanggaran ada konsekuensi dari Fakultas penyelenggara. (c). Sebaiknya PPL Fakultas Tarbiyah dilaksanakan pada awal tahun ajaran di sekolah, yaitu bulan Juli, sehingga mahasiswa mengikuti kegiatan utuh satu semester, mulai dari Masa Orientasi Siswa (MOS) sampai pengisian raport siswa. (d). Untuk mata kuliah dasar-dasar kependidikan mahasiswa perlu didekatkan dengan habitatnya yaitu sekolah. Setiap mata kuliah ilmu kependidikan harus ada kaitannya dengan sekolah dalam bentuk Teori, Praktik dan Lapangan. Untuk mata kuliah ini ketiga komponen ini harus dilakukan. (d). Mahasiswa praktikan harus beretikan yang baik, datang tepat waktu, mengikuti program sekolah, seperti apel pagi, sholat duha berjamaah. Dari pakaian juga tidak selalu memakai jaket almamater.

\section{REFERENSI}

Asfandiyar, A. Y. (2009). Kenapa Guru Harus Kreatif. Jakarta: Mizan Media Utama.

Aunurrahman, D., \& Pd, M. (2009). Belajar dan pembelajaran. Bandung: Alfabeta.

Chori, S. (1995). Ortopedagogik Anak Tunadaksa. Jakarta: Departemen Pendidikan dan Kebudayaan.

Dimyati, M. (2006). Belajar dan pembelajaran. Jakarta: Rineka Cipta.

Djunaidi, H. (2001). Reformasi Pendidikan dalam Konteks OtonomiDaerah.

Fathurrochman, I., Hariani, D., Hamengkubuwono, H., Arsil, A., Muhammad, A., \& Ristianti, D. H. (2020). The Development of Student Academic Administration Services in Higher Education. International Journal of Psychosocial Rehabilitation, 24(8), 4764-4771.

Fathurrochman, I., Ristianti, D. H., \& bin Mohamed Arif, M. A. S. (2019).

Revitalization of Islamic Boarding School Management to Foster the Spirit of Islamic Moderation in Indonesia. Jurnal Pendidikan Islam, 8(2), 239-259.

Hamalik, O. (1994). Pengembangan Kurikulum dan Pembelajaran. Dasar dan Strategi Pelaksanaannya di Perguruan Tinggi (Jakarta: Triganda Karya.

Hashona, A. H. (2016). Kajian pelaksanaan praktik pengalaman lapangan (PPL) mahasiswa fakultas ilmu tarbiyah dan keguruan IAIN Walisongo Semarang. Cendekia: Jurnal Kependidikan Dan Kemasyarakatan, 12(2), 333-352.

Hawi, A. (2013). Kompetensi guru PAI. Jakarta: Rajawali Pers. 
Krippendorff, K. (1991). Content Analysis: Introduction Its Theory and Methodology", Alih Bahasa Farid Wajidi. Analisis Isi: Pengantar Teori dan Metodologi.

Muhadjir, N. (2016). Metodelogi penelitian. Yogyakarta: Rake Sarasin.

Mulkhan, A. M. (1993). Paradigma intelektual Muslim: pengantar filsafat pendidikan Islam dan dakwah. Sipress.

Nasbi, I. (2017). Manajemen kurikulum: Sebuah kajian teoritis. Idaarah: Jurnal Manajemen Pendidikan, 1(2).

Nashori, F. N. (2003). Potensi-potensi manusia. Pustaka Pelajar.

Nasution, S. (1993). Pengembangan kurikulum. Bandung: PT. Citra Aditya Bakti.

Patton, M. Q. (1980). Qualitative evaluation methods.

Putraa, S. A., Soesatyob, Y., AKc, M., \& Tunik, L. Asking Local Government to Commit to Implementing Inclusive Schools: Its Policy and Practice.

Qomario, Q., Kurniasih, S., \& Anggraini, H. (2018). Studi Analisis Latar Belakang Pendidikan, Sertifikasi Guru Dan Usia Guru Paud Di Kota Bandar Lampung Berdasarkan Hasil Nilai Uji Kompetensi Guru (UKG). Jurnal Caksana: Pendidikan Anak Usia Dini, 1(02).

Rahayu, M. (2015). Pelaksanaan standar pengelolaan pendidikan di sekolah dasar kecamatan Ngemplak, Sleman. Jurnal Penelitian Ilmu Pendidikan, 8(1).

Ristianti, D. H., \& Fathurrochman, I. (2020). Penilaian Konseling Kelompok. Deepublish.

Roger, E. M. (1983). Diffusion of innovation Society.

Sagala, S. (2009). Kemampuan Profesional Guru dan Tenaga Kependidikan: Pemberdayaan guru, tenaga kependidikan, dan masyarakat dalam manajemen sekolah. Alfabeta.

Suharsimi, A. (2010). Prosedur penelitian: suatu pendekatan praktik (edisi revisi). Jakarta: Rineka Cipta, 1.

Sulfemi, W. B. (2019). Manajemen Kurikulum di Sekolah.

Sutarto, S., Sari, D. P., \& Fathurrochman, I. (2020). Teacher strategies in online learning to increase students' interest in learning during COVID-19 pandemic. Jurnal Konseling dan Pendidikan, 8(3).

Sutopo, H. B. (2002). Metodologi penelitian kualitatif.

Zohar, D., Marshall, I., \& Astuti, R. (2001). SQ: Memanfaatkan kecerdasan spiritual dalam berpikir integralistik dan holistik untuk memaknai kehidupan. Mizan. 